\title{
Prospects for an integrated control of Loranthaceae species parasitizing Vitellaria paradoxa C. F. Gaertn in Burkina Faso
}

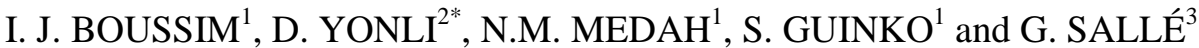 \\ ${ }^{1}$ Université de Ouagadougou, Unité de formation et de recherche en sciences de la vie et de la terre, \\ B.P. 7021, Ouagadougou, Burkina Faso. \\ ${ }^{2}$ Institut de l'Environnement et de Recherches Agricoles, 04 B.P. 8645 Ouagadougou 04, Burkina Faso. \\ ${ }^{3}$ Université Pierre et Marie Curie, Laboratoire de Cytologie Expérimentale et de Morphogenèse Végétale, \\ 4 Place Jessieu, Bât. N2, Case courrier 150, 752552 Paris cedex 05, France. \\ *Corresponding author; E-mail: yonlidjibril@yahoo.fr ;d.yonli313@gmail.com
}

\begin{abstract}
This study investigated the potential components of an integrated management of Loranthaceae species (mistletoes) which constitute a major constraint to the survival and fruit production of many trees such as Vitellaria paradoxa in West Africa. Three types of pruning, five doses of each of two herbicides and host resistance were evaluated in mistletoe-infested parklands. Natural enemies were surveyed with a view to biological control. Pruning of the host branch along with the parasite's haustorium (endophytic system) led to the total elimination of the parasite. When the endophytic system was spared, the time of pruning and species of parasite significantly influenced the number of sprout stalks per tuff. Their interaction was also significant. Death of at least $80 \%$ of treated Loranthaceae tufts was recorded for doses of $15 \mathrm{~g} \mathrm{l}^{-1}$ of glyphosate and $20 \mathrm{~g} \mathrm{l}^{-1}$ of 2,4-D. The artificial infestation of stands with parasite seeds revealed the likely existence of genetic resistance to mistletoe in $V$. paradoxa. The agroforestry parkland survey showed that birds, chiefly Pogoniulus chrysonocus, and insects are potential natural enemies of Loranthaceae. Results showed that Loranthaceae control could be achieved with techniques already used to successfully manage weeds. However, there is need to improve control components and their integration to successfully manage mistletoes in Burkina Faso.
\end{abstract}

(c) 2012 International Formulae Group. All rights reserved.

Keywords: Vitellaria paradoxa, Loranthaceae, mechanical, herbicides, host resistance, bio-control

\section{INTRODUCTION}

Vitellaria paradoxa C. F. Gaertn (shea tree) mainly grows in 19 African countries (Wara, 2011). Among those, Burkina Faso has a high potential production with an average density of 30 trees $^{-1}$, or about 195 million shea trees (John, 2000). It is the most widespread parkland species in the country because farmers actively select and preserve "plus-trees" during the clear-cut of their cropping areas. V. paradoxa thus constitutes the main tree species of the country's agroforestry parklands (Lovett and Haq, 2000). The fresh pulp of the fruit, the nuts and the butter extracted are the most valued byproducts of shea tree. Those products play 
important social and economic roles in Burkina Faso. Indeed, the shea butter is locally consumed by $88 \%$ of households in rural areas and by $25 \%$ of urban households (Bambio, 2007). It is frequently used for domestic purposes such as cooking, lighting, soap processing or as a skin moisturizer (Lamien et al., 2006). The average harvested production of dried shea nuts was estimated at about 780,000 tons per year (Bambio, 2007). The last production represented $10 \%$ of the potential production of shea trees which currently exploited in Burkina Faso, third largest shea nut producer in the world after Nigeria and Mali (Bambio, 2007). The export of shea nuts creates significant revenues for the country. Indeed, Burkina Faso exports about 650 tons of shea nut butter per year for a total value of about 2 million Euros (Bambio, 2007). The subsequent sale of derived products from shea nuts exceeds 10 million Euros for country buyers (Bambio, 2007).

Shea trees are threatened by limiting factors whose most significant are climatic variability, human activities (bush fires, excessive cutting of wood), pest attacks, (Boussim, 2002) and the parasitic plants belonging to Loranthaceae (Sallé et al., 1991; Boussim et al., 1993a). Due to the influence of national policies, Vitellaria paradoxa was classified as a protected-tree throughout Burkina Faso's territory and negative human impacts on "plus-trees" were minimized. Caterpillar attacks are mainly confined to the western part of the country and their impact is limited to the defoliation of shea trees. Defoliation of trees by caterpillars occurs mainly in the western part of the country. But mistletoes infest shea trees throughout the country, decreasing growth, reducing fruit yield, altering wood quality, and exposing the weakened tree to other diseases or even resulting in its death. In Ivory Coast, eleven species of Loranthaceae have been inventoried (Soro et al., 2010). In that country,
Loranthaceae infect cultivated trees such as rubber trees cocoa, avocado and citrus trees (Soro et al., 2010) and they significantly reduce their production capacity (Sonké et al., 2000; Koffi, 2004). The Loranthaceae family contains 950 species distributed in 77 genera (Polhill and Wiens, 1998). The species are mostly shrubs or bushes that grow as hemiparasites (parasites also capable of photosynthesis) on the branches of their hosts. Six of these species: Agelanthus dodoneifolius (D. C.) Polh. \& Wiens, Englerina lecardii (Engl.) Balle, Globimetula cupulata (D. C.) Van Tieghem, Tapinanthus bangwensis (Engl. \& K. Krause) Danser, T. globiferus (A. Rich.) Van Tieghem and T. ophiodes (Sprague) Danser were inventoried in Burkina Faso (Boussim, 2002). All of these infect at least 154 wild and cultivated woody trees species, belonging to 96 genera and 42 families (Boussim et al., 2004). Boussim's investigation in 1991 revealed that about $95 \%$ of shea trees were infected by four species of Loranthaceae: A. dodoneifolius, T. globiferus, $T$. ophiodes and T. bangwensis. The literature reveals very little information about the extent of damages caused by Loranthaceae on forest trees, and about the control techniques.

The objectives of the present study were: (1) to evaluate three potential control techniques, namely mechanical, chemical and host plant resistance, and (2) to inventory natural enemies that might serve as biocontrol agents.

\section{MATERIALS AND METHODS}

\section{Study area}

The experiments were carried out in 1999 and 2000. Mechanical control and host resistance to Loranthaceae were experimented at the agroforestry parklands of Toudoubwéogo (001 53 ' $\mathrm{W}$ and $\left.12^{\circ} 46^{\prime}\right)$. Chemical control was tested in the agroforestry parkland located at Saria Research Station $\left(2^{\circ} 09^{\prime} \mathrm{W}\right.$ and $\left.12^{\circ} 16^{\prime} \mathrm{N}\right)$ of 
the National Institute of Environmental and Agricultural Research (INERA).

\section{Materials}

Vitellaria paradoxa parklands heavily infected by Loranthaceae were used for the experiments. Mechanical control and varietal resistance were investigated. Two herbicides were tested on Loranthaceae. These herbicides were Calliherbe, with the active ingredient 2,4-dichlorophenoxyacetic acid or 2,4-D and Roundup or Kalach, with glyphosate or 2-Nphosphonomethylglycin as active ingredient.

\section{Mechanical control}

Mechanical control consisted of manual destruction of the parasite tufts. Shea trees were selected in April because during this period, shea trees lose almost all of their leaves. This allows one to view, even from a long distance, the entire foliage of Loranthaceae.

The species of Loranthaceae, parasitizing shea trees were Agelanthus dodoneifolius, Tapinanthus globiferus and $T$. ophiodes. Three treatments were performed three times according to the growing season of shea trees in Burkina Faso: in April (period corresponding to the recovery of vegetation), in June (full growing season) and in November (beginning of the period of slow vegetative activity):

Firstly, total pruning of shea trees in July including Agelanthus dodoneifolius and Tapinanthus globiferus. Treated shea trees were followed up during additional years to observe their regrowth and fruit production ability.

- Secondly, pruning mistletoe shoots on shea trees infested with A. dodoneifolius, T. globiferus and T. ophiodes while leaving the endophytic system (haustorium) intact. The mistletoes were selected according to their accessibility. At each pruning, the stalks were counted before cutting.
Thirdly, cutting of infected branches of shea tree with parasite tufts, just above the attachment point of the mistletoe (haustorium).

The experimental design was a completely randomized block and the treatments were replicated three times for each parasite species.

The observations included:

1) the numbers of sprouts noted at 3, 6, 9, 12 15 and 18 weeks after pruning (WAP);

2) the phenological and morphological characteristics of sprouts;

3) hand-thick sections were taken from young parasitized branches of shea for study of the parasite haustorium.

\section{Chemical control}

The number of tufts was counted before the application of herbicides. Herbicides were applied by foliar spray until run-off on the tufts of Loranthaceae, Agelanthus dodoneifolius, Tapinanthus. globiferus and T. ophiodes. The herbicides were separately applied and the treatments were: 1) T0: distilled sterile water (control, without application of herbicide) ; 2) $\mathrm{T} 1: 15 \mathrm{~g}$ $\mathrm{l}^{-1}$ of glyphosate ; 3) T2: $20 \mathrm{~g} \mathrm{l}^{-1}$ of glyphosate ; 4) T3: $25 \mathrm{~g} \mathrm{l}^{-1}$ of glyphosate ; 5) T4: $35 \mathrm{~g} \mathrm{l}^{-1}$ of glyphosate ; 6) T5: $45 \mathrm{~g} \mathrm{l}^{-1}$ of glyphosate ; 7) T6: $15 \mathrm{~g} \mathrm{l}^{-1}$ of 2,4-D ; 8) T7: $20 \mathrm{~g} \mathrm{l}^{-1}$ of 2,4-D ; 9) $\mathrm{T} 8: 25 \mathrm{~g} \mathrm{l}^{-1}$ of 2,4-D ; 10) T9: $35 \mathrm{~g} \mathrm{l}^{-1}$ of 2,4D ; 11) T10: $45 \mathrm{~g} \mathrm{l}^{-1}$ of 2,4-D. Three replications were used for each treatment.

The observations were the following: 1) the effect of herbicides on host shea tree; 2) the effectiveness of herbicides 28 days after application (DAA) which consisted in counting killed stalks per mistletoe tuft.

\section{Varietal resistance}

During the parkland survey, we noted the presence of uninfected shea trees free of Loranthaceae species infestation cohabiting with heavily infested shea trees stands. Thus, a difference in susceptibility from individual 
shea trees to Loranthaceae species attack was assumed. To highlight the existence of varietal resistance in shea tree, experiment based on artificial infection was carried out on some uninfected shea trees. For artificial infection, ripe fruits of $A$. dodoneifolius and $T$. globiferus were collected, pressed; the epicarp removed and the rest constituting a berry. Five uninfected shea trees were selected in the agroforestry parkland of the village of Toudoubwéogo. Each shea tree was artificially infected with 60 berries of $A$. dodoneifolius and with 60 berries of $T$. globiferus, during January and April 1999, respectively. Indeed, the berries were deposed on the top of the branches and adherence assured through viscin (Boussim et al., 1993b). The test was repeated in 2000 upon the same shea tree, in the same periods with the same number of berries.

\section{Biological control}

Potential biological enemies of Loranthaceae species were inventoried during parkland surveys. Organisms inflicting damage that could affect the survival of Loranthaceae species under natural conditions were inventoried.

\section{Statistical analysis}

The number of mistletoe stalks regrowing after pruning and the percentage of stalks killed by herbicide application were compared using SAS (Statistical Analysis System) Sofware. A separation of means was performed using the Student-Newman-Keuls test. The number of Loranthaceae stalks recorded before pruning or herbicide application was used as a covariate in the separation of means.

\section{RESULTS}

\section{Mechanical control}

The total pruning of shea tree resulted in the complete elimination of Loranthaceae. Consequently, shea tree gained a satisfactory level of regrowth and an early flowering after the third year and fruit production highly improved. Thus, eradication of the parasite was definitive following the cutting down of the host branch. No sprout of the parasite was possible after the elimination of aerial parts along with the haustorium.

However, the partial destruction of the haustorium did not prevent the regrowth of Loranthaceae. The ANOVA analysis revealed a significant difference between Loranthaceae species for the numbers of sprouts after 3 WAP (Table 1). When the pruning coincided with the period of the vegetation regrowth (in April) or with the full growing season (in June), the highest sprout number was recorded with Tapinanthus globiferus at 6, 12, 15 and 18 WAP. The number of sprouts counted at 6 , 9 and 12 WAP with Agelanthus dodoneifolius and $T$. ophiodes were statistically equivalent. However, that number observed at 15 and 18 WAP with A. dodoneifolius was significantly lower than that of $T$. ophiodes (Table 1). When the pruning was done at the end of the growing season (November), no significant differences were found for the numbers of shoots present at 3,6,12 and 15 WAP for all three Loranthaceae species.

The two Tapinanthus species generated sprouts whose number at 18 WAP was significantly higher while A. dodoneifolius gave no sprout (Table 1). The period of cutting and the species of Loranthaceae significantly influenced the number of sprouts per tuff from 3 WAP to 18 WAP and their interactions were significant from 6 WAP (Table 2).

The observation of growth stages of sprouts showed that the budding was started from the spared stump of the stalk, and the significance of sprout number varied according to the diameter of the grounding of the destroyed stalk. At the haustorium, the host and the parasite grew together. From $A$. dodoneifolius, the number of sprouts after cutting was low. Hypertrophy at the 
attachment point of $A$. dodoneifolius on the host was constituted of a tangle of tissues of individual, host and parasite. The observations performed on hand-thick sections of growing haustoria from both species suggested different patterns of development.

\section{Chemical control}

Localized drying of shea leaves treated with the herbicide was observed. Herbicide damage of the host was minimized due to natural defoliation of shea trees at the time of herbicide application. When trees leafed out in the spring, shea branches bearing treated parasite tufts generated new leaves and flowered normally like untreated controls.

Symptoms of herbicides on treated mistletoes included darkening of the leaves, leaf necrosis, leaf and flowers drop, and the gradual drying of twigs and fruits. These symptoms were noted before the counting of destroyed stalks (28 DAA). ANOVA revealed a significant difference between treatments (Table 3). All doses of both herbicides significantly reduced the number of living mistletoe stalks compared to the control. The percentage of killed stalks at 28 DAA increased with increasing dose from 15 to 25 $\mathrm{g} \mathrm{l}^{-1}$ for the glyphosate and from 15 to $35 \mathrm{~g} \mathrm{l}^{-1}$ for the 2,4-D. Total destruction of Loranthaceae stalks was observed at 28 DAA from $25 \mathrm{~g} \mathrm{l}^{-1}$ with the glyphosate and from 35 $\mathrm{g} \mathrm{l}^{-1}$ with the 2,4-D (Table 3).

\section{Varietal resistance of Vitellaria paradoxa}

One among shea trees with branches that were artificially infected with berries bore no parasite seedling and therefore appeared to have no susceptibility. Loranthaceae germination not being dependent on the host species, the viable seeds used have probably germinated. Indeed, penetrations of tissues and first leaves of Loranthaceae were sometimes observed. But no seedling growth has exceeded the step of two leaves from "mistletoe-resistant" shea tree, suggesting the existence of a barrier that would prevent the growth of the parasite.

\section{Natural biological enemies}

Two categories of natural potential enemies of Loranthaceae were identified during parkland surveys. Birds were the first category which destroyed Loranthaceae seeds. Indeed, the embryos of seeds stuck by fruiteater birds, mainly Pogoniulus chrysonocus (= "Yellow-fronted barbet) were extracted and eaten by other birds that were probably granivores.

Insects composed the second category with three types of nuisance to Loranthaceae. The first one is the destruction of haustorium caused by ant activities. Indeed during the surveys, some tufts of $T$. ophiodes were withering. The ants dug large galleries in the haustorium. Those galleries affected the normal functioning causing the desiccation of the haustorium followed by the parasite death. The second nuisance of insects is the destruction of Loranthaceae leaves. We observed a large population of $T$. ophiodes infecting Acacia olocericea at Saria Station Research and some tufts of T. globiferus on shea trees in the village of Pô; the leaves and their terminal buds are highly destroyed by the larva of caterpillars. Large colonies of caterpillars laid on the leaves and terminal buds of Loranthaceae that were subsequently destroyed by the larva. Coleopteran attacks on Loranthaceae floral organs constituted the third nuisance. Those attacks were observed on tufts of $T$. globiferus infecting shea tree and flowers became unable to fructify. Indeed, the manual opening of Loranthaceae flowers revealed the presence of small coleopteran and their eggs. The reproductive organs of Loranthaceae were thereby destroyed by these insects. 
Table 1: Number of Loranthaceae sprouts after the pruning.

\begin{tabular}{|c|c|c|c|c|c|c|c|}
\hline \multirow{2}{*}{$\begin{array}{l}\text { Cutting } \\
\text { time }\end{array}$} & \multirow{2}{*}{$\begin{array}{l}\text { Parasitic } \\
\text { plantes }\end{array}$} & \multicolumn{6}{|c|}{ Number of Loranthacea sprouts } \\
\hline & & 3 wap & 6 wap & 9 wap & 12 wap & 15 wap & 18 wap \\
\hline \multirow[t]{5}{*}{ Aprril } & A. dodoneifolius & $3.00 \mathrm{a}$ & $3.00 \mathrm{~b}$ & $3.00 \mathrm{a}$ & $2.00 \mathrm{~b}$ & $2.00 \mathrm{c}$ & $2.00 \mathrm{c}$ \\
\hline & T. globiferus & $5.33 \mathrm{a}$ & $7.67 \mathrm{a}$ & $7.67 \mathrm{a}$ & $7.67 \mathrm{a}$ & $7.00 \mathrm{a}$ & $7.00 \mathrm{a}$ \\
\hline & T. ophiodes & $3.33 \mathrm{a}$ & $4.00 \mathrm{~b}$ & $4.67 \mathrm{a}$ & $3.67 \mathrm{~b}$ & $3.67 \mathrm{~b}$ & $3.67 \mathrm{~b}$ \\
\hline & Std. Error & 0.61 & 0.92 & 0.90 & 1.00 & 0.83 & 0.83 \\
\hline & $\mathrm{P}$ value & 0.4786 & 0.0990 & 0.1574 & $\begin{array}{c}0.0017 \\
3\end{array}$ & 0.0045 & 0.0045 \\
\hline \multirow[t]{5}{*}{ June } & A. dodoneifolius & $3.67 \mathrm{a}$ & $2.33 \mathrm{~b}$ & $1.67 \mathrm{~b}$ & $2.00 \mathrm{~b}$ & $2.00 \mathrm{c}$ & $2.00 \mathrm{c}$ \\
\hline & T. globiferus & $4.33 \mathrm{a}$ & $11.00 \mathrm{a}$ & $8.00 \mathrm{a}$ & $8.00 \mathrm{a}$ & $8.33 \mathrm{a}$ & $7.67 \mathrm{a}$ \\
\hline & T. ophiodes & $2.00 \mathrm{a}$ & $3.67 \mathrm{~b}$ & $3.67 \mathrm{~b}$ & $4.00 \mathrm{~b}$ & $4.00 \mathrm{~b}$ & $4.00 \mathrm{~b}$ \\
\hline & Std. Error & 0.67 & 1.52 & 0.97 & 0.93 & 0.98 & 0.86 \\
\hline & $\mathrm{P}$ value & 0.7383 & 0.0894 & 0.0231 & 0.0404 & 0.0066 & 0.0148 \\
\hline \multirow[t]{5}{*}{ November } & A. dodoneifolius & $2.67 \mathrm{a}$ & $0.33 \mathrm{~b}$ & $0.00 \mathrm{~b}$ & $0.00 \mathrm{~b}$ & $0.00 \mathrm{~b}$ & $0.00 \mathrm{c}$ \\
\hline & T. globiferus & $2.33 \mathrm{ab}$ & $2.67 \mathrm{a}$ & $2.00 \mathrm{a}$ & $1.67 \mathrm{a}$ & $2.00 \mathrm{a}$ & $1.33 \mathrm{~b}$ \\
\hline & T. ophiodes & $1.00 \mathrm{~b}$ & $1.00 \mathrm{~b}$ & $2.33 \mathrm{a}$ & $1.67 \mathrm{a}$ & $1.67 \mathrm{a}$ & $1.67 \mathrm{a}$ \\
\hline & Std. Error & 0.33 & 0.41 & 0.41 & 0.31 & 0.32 & 0.29 \\
\hline & $\mathrm{P}$ value & 0.1111 & 0.0744 & 0.0494 & 0.0494 & 0.0044 & 0.0001 \\
\hline
\end{tabular}

Table 2: Effect of Loranthaceae species, the pruning time and their interactions on the regeneration of Loranthaceae after the pruning sparing the haustorium.

\begin{tabular}{lcccccc}
\hline & \multicolumn{7}{c}{ Trait Mean square of sprouts number of Loranthaceae } \\
\hline Source of variation & 3 wap & 6 wap & 9 wap & 12 wap & 15 wap & 18 wap \\
\hline Replication & 4.7037 & 4.7037 & 2.7778 & 3.5926 & 1.8148 & 0.7037 \\
\hline Loranthaceae species & $8.0370 * *$ & $69.1481 * * *$ & $42.3333 * * *$ & $45.0370 * * *$ & $45.0370 * * *$ & $36.1481 * * *$ \\
\hline pruning time & $8.4815 * *$ & $48.0370 * * *$ & $34.3333 * * *$ & $35.7037 * * *$ & $32.9259 * * *$ & $34.7037 * * *$ \\
\hline $\begin{array}{l}\text { Loranthaceae species vs } \\
\text { pruning time }\end{array}$ & 1.7037 & $9.3148 *$ & $5.3333 * *$ & $5.5926 * *$ & $4.6481 * * *$ & $5.2037 * * *$ \\
\hline Error & 2.1620 & 3.3704 & 1.7361 & 1.3426 & 0.8981 & 0.8287 \\
\hline \multicolumn{1}{l}{ Asterisk indicates the significance: $* \mathrm{P}</ 0.10 ; * * \mathrm{P}</ 0.05 ; * * * \mathrm{P}</ 0.01 ;$ wap: Week after the pruning } &
\end{tabular}


Table 3: Percentage of destroyed stalks from treated Loranthaceae species.

\begin{tabular}{lc}
\hline Treatments & $\begin{array}{c}\text { Percentage of destroyed } \\
\text { stalks (\%) }\end{array}$ \\
\hline Control & $0.00^{\mathrm{g}}$ \\
$15 \mathrm{~g} \mathrm{l}^{-1}$ Glyphosate & $85.70^{\mathrm{c}}$ \\
$20 \mathrm{~g} \mathrm{l}^{-1}$ Glyphosate & $80.00^{\mathrm{e}}$ \\
$25 \mathrm{~g} \mathrm{l}^{-1}$ Glyphosate & $100.00^{\mathrm{a}}$ \\
$35 \mathrm{~g} \mathrm{l}^{-1}$ Glyphosate & $100.00^{\mathrm{a}}$ \\
$45 \mathrm{~g} \mathrm{l}^{-1}$ Glyphosate & $100.00^{\mathrm{a}}$ \\
$15 \mathrm{~g} \mathrm{l}^{-1} 2,4-\mathrm{D}$ & $50.00^{\mathrm{f}}$ \\
$20 \mathrm{~g} \mathrm{l}^{-1} 2,4-\mathrm{D}$ & $84.60^{\mathrm{d}}$ \\
$25 \mathrm{~g} \mathrm{l}^{-1} 2,4-\mathrm{D}$ & $87.50^{\mathrm{b}}$ \\
$35 \mathrm{~g} \mathrm{l}^{-1} 2,4-\mathrm{D}$ & $100.00^{\mathrm{a}}$ \\
$45 \mathrm{~g} \mathrm{l}^{-1} 2,4-\mathrm{D}$ & $100.00^{\mathrm{a}}$ \\
\hline Std. Error & 5.17 \\
$\mathrm{P} \mathrm{value}^{\text {The means followed by the same letter are not significantly different according to the Student- }}$ \\
Newman-Keuls' test. \\
Std. Error: Standard Error
\end{tabular}

\section{DISCUSSION}

Mechanical control against epiphyte parasitic Loranthaceae through the pruning of the host branch after their haustorium allowed a definitive elimination of the parasite. When the pruning saved the haustorium, the period of vegetative dormancy of the host would be appropriate for its implementation. The pruning is thereby the simplest curative and affordable method. However, parasitized trees may not be able to support a heavy pruning (Boussim et al., 2004). When the pruning was made downstream of the haustorium, the number of regenerated sprouts would be according to the diameter of the grounding of the parasite stalk destroyed while the growth rate of sprouts depended on the period of the year. Thus, the period from November to midMarch is a slowdown of the vegetative activity for most woody species in the Sahel, including the Loranthaceae and their main hosts such as Vitellaria paradoxa. During that time, the harmattan blew in this country and dried in addition with ambient humidity that was at a lowest level. Most species lose their leaves and their vegetative growth slowed down. The rate of tuft sprouting from lopped
Loranthaceae during this period is very low, almost null. The total eradication of the parasite was thereby obtained with the pruning experiment implemented in November while many tufts that were flowering in October in the same year were recorded with the pruning carried out in April. However, mechanical control depends on the accessibility of the parasite and the extent of the infected parklands while its effectiveness depends on the level and the timing of the pruning implementation. Soro et al. (2010) emphasised that the mechanical control method against Loranthaceae is perilous because of the host tree fragility, branches brittle easily.

The destruction percentage varied between 80 and $100 \%$ with the glyphosate and between 50 and $100 \%$ with the 2,4-D. The glyphosate with the dose of $15 \mathrm{~g} \mathrm{l}^{-1}$ and 2,4-D at $20 \mathrm{~g} \mathrm{l}^{-1}$ led to a destruction at least $80 \%$ of Loranthaceae tufts, respectively. Thus, to minimize the investment costs and the applied amounts of pesticides in the environment, the dose $15 \mathrm{~g} \mathrm{l}^{-1}$ of glyphosate and $20 \mathrm{~g} \mathrm{l}^{-1}$ of 2,4$\mathrm{D}$ may be recommended in Loranthaceae management. Both herbicides highly 
destroyed the tufts of Loranthaceae and therefore reduced their negative impact on their hosts (shea trees). One application per year is sufficient. Their efficacy was previously revealed on root parasitic plants. Indeed, the 2,4-D effectively controls Striga (Carsky et al., 1994; Traoré et al., 2000 and 2001; Radi, 2007), while the glyphosate is effective on Orobanche (Gressel, 2009) and Striga hermonthica (Traoré et al., 2001). For Loranthaceae controlling, these herbicidal effects did not completely eradicate the parasite on the treated parts of shea trees. However, both herbicides contributed to reduce the depressive effect of Loranthaceae on their hosts and to prevent further fruit production. Despite the effectiveness of both herbicides on Loranthaceae, it seems unrealistic to consider a general chemical treatment against these parasitic plants in African countries for economic and safety reasons. Indeed, farmers' infatuation will be limited due to the high cost of herbicides and spraying equipment, the technical implementation and the extent of Loranthaceae-infected parklands. Mony et al. (2011) emphasized that the methods most often used in Cameroon to control the spread of the Loranthaceae are either mechanical (e.g., involving the elimination of the infested branch) or chemical.

This study also revealed that the probable existence of varietal resistance to Loranthaceae in Vitellaria paradoxa would be an investigation pathway. This varietal resistance did not prevent seed germination or seedling attachment of Loranthaceae to their hosts. The same observation was made on the resistance mechanism of some cereal cultivars in Striga controlling (Kuiper et al., 1998). The existence of differences in cultivar susceptibility against Striga hermonthica has been highlighted among sorghum cultivars (Omanya et al., 2004; Rodenburg et al., 2006) and maize (Zea mays L.) cultivars (Kim et al., 1998). Our results confirmed that of Hariri (1990) and Dibong et al. (2009) from their experiments on artificial infestations with other species of Loranthaceae. Indeed, Hariri
(1990) found differences in susceptibility of some poplar cultivars (Salicaceae) to Gui (Viscum album L.) (Loranthaceae) and Dibong et al. (2009) reported the resistance of Mangifera indica L. (Anacardiaceae) and Persea americana Mill. (Lauraceae) and the high susceptibility of Dacryodes edulis (G. Don.) Lam. (Burseraceae) to Tapinanthus ogowensis (Engler) Danser (Loranthaceae). Hariri (1991) identified the tannins, flavonoids and lignins as part of the factors involved in Gui- resistant popular.

It would be appropriate to demonstrate the existence of susceptibility differences in shea varieties against Loranthaceae by using biomolecular technologies that should help to identify resistant shea varieties to Loranthaceae. Then, the multiplication and domestication of shea resistant varieties could be implemented by vegetative propagation techniques such as grafting techniques which were developed in Burkina Faso by Sanou et al. (2004). Thus, the using of resistant individuals should be a preventive control method of Loranthaceae.

The available literature does not provide comprehensive information on natural enemies of Loranthaceae in Africa. This study showed that insects and birds are the potential enemies of Loranthaceae. Two insect species, Smicronys guineanus and Smicronys umbrinus (Coleoptera: Curculionidea) proved to be effective for biological control of the parasitic weed Striga hermonthica (Del.) Benth. (Scrophulariaceae) (Traoré et al., 1996). Regarding insect species and their damages on Loranthaceae, our results are similar to that of Mony et al. (2011) who inventoried in Cameroon eight species of ants; two were arboreal-dwelling and six were grounddwelling, arboreal-foraging species. Bird damages described in this study were also reported by Sallé et al. (1993) on Viscum album L.. The systematic determination of the species of natural enemies causing inventoried damages is necessary. Besides, further studies are needed to highlight the interactions/relationships between shea trees, the species of Loranthaceae and natural 
enemies with the aim of controlling parasitic plants.

\section{ACKNOWLEDGEMENTS}

The authors are grateful to the project ENRECA-Botanique/DANIDA for funding this study. They also thank INERA/CNRST (Burkina Faso) for allowing them to use the infrastructure from Saria Research Station.

\section{REFERENCES}

Bambio ZF. 2007. http://www.investirbf.info/index.php?option= com_content $\&$ view $=$ article $\&$ id $=15:$ karite $\&$ catid $=28: a$ griculture.

Boussim IJ. 1991. Contribution à l'étude des Tapinanthus parasites du karité au Burkina Faso. Thèse de doctorat de $3^{\mathrm{e}}$ cycle, Université de Ouagadougou, Ouagadougou, $152 \mathrm{p}$.

Boussim IJ, Sallé G, Guinko S. 1993a. Tapinanthus parasite du karité au Burkina Faso. $1^{\mathrm{e}}$ partie : Identification et distribution. Bois et Forêts des Tropiques, 238: 53-58.

Boussim IJ, Sallé G, Guinko S. 1993b. Tapinanthus parasite du karité au Burkina Faso. $2^{\mathrm{e}}$ partie : Phénologie, biologie et dégâts. Bois et Forêts des Tropiques, 238: 59-65.

Boussim IJ. 2002. Les phanérogames parasites du Burkina Faso : inventaire, taxonomie, écologie et quelques aspects de leur biologie. Cas particulier des Loranthaceae parasites du karité. Thèse de Doctorat d'Etat ès Sciences Naturelles, Ouagadougou, Burkina Faso, 285 pp. +38 plates.

Boussim IJ, Guinko S, Tuquet C, Sallé G. 2004. Mistletoes of the agroforestry parklands of Burkina Faso. Agroforestry Systems, 60: 39-49.

Carsky RJ, Singh L, Ndikawa R. 1994. Effect of herbicide and handweeding on current and subsequent season Striga hermonthica density on sorghum. International Journal of Pest Management, 40(2): 111-116.
Dibong SD, Eugone Obiang NL, Ndongo D, Priso RJ, Taffouo V, Fankem H, Sallé G. 2009. Artificial infestation of Tapinanthus ogwensis (Engler) Danser (Loranthaceae) on three host species in the Logbessou plateau (Douala, Cameroon). African Journal of Biotechnology, 8(6): 1044-1051.

Gressel J. 2009. Crops with target-site herbicide resistance for Orobanche and Striga control. Pest Manag. Sci., 65: 360-365.

Hariri EB, Jeune B, Baudino S, Urech K, Sallé G. 1991. Elaboration d'un coefficient de résistance au gui chez le chêne, Can. J. Bot., 70: 1239-1246.

Hariri EB, Sallé G, Andary C. 1990. Mécanisme de résistance de 4 cultivars de peuplier en réponse à l'attaque du gui (Viscum album L.). C.R. Acad. Sci. Paris, 311(3): 439-444.

John LE. 2000.- Projet "PSD - GTZ". Note de présentation du projet "Gestion des terroirs et des collectivités: Piste à bétail, amende de karité, fosse fumière, embouche, Burkina Faso, p. 43-51.

Kim SK, Fajemisin JM, The C, Adepoju A, Kling J, Badu-Apraku B, Versteeg M, Carsky R, Lagoke STO. 1998. Development of synthetic maize populations for resistance to Striga hermonthica. Plant Breeding, 117: 203209.

Koffi EK, Elabo AA, Gnagne YM. 2004. Qualité sélective des paramètres physiologiques dans la sélection précoce de l'hévéa (Hevea brasiliensis (Kunth) Müll. Arg.). Agronomie Africaine, 16(3): 1-10.

Kuiper E, Groot A, Noordover CME, Pieterse AH, Verkleij ACJ. 1998. Tropical grasses vary in their resistance to Striga aspera, S. hermonthica, and their hybrids. Can. J. Bot., 76: 2131-2144.

Lovett NP and Haq N. 2000. Evidence for anthropic selection of the Sheanut tree (Vitellaria paradoxa). Agrofor. Syst., 48: 273-289. 
Lamien N, Boussim JI, Nygard R, Ouédraogo JS, Odén PC, Guinko S. 2006. Mistletoe impact on Shea tree (Vitellaria paradoxa C.F. Gaertn.) flowering and fruiting behaviour in savanna area from Burkina Faso. Environmental and Experimental Botany, 55: 142-148.

Mony R, Dibong SD, Ondoua JM, Bilong.Bilong CF. 2011. Study of hostparasite relationship among Loranthaceae flowering ShrubsMyrmecophytic fruit trees-Ants in Logbessou district, Cameroon. Annual Review \& Research in Biology, 1(3): 6878.

Omanya GO, Haussmann BIG, Hess DE, Reddy BVS, Kayentao M, Welz HG, Geiger HH. 2004. Utility of indirect and direct selection traits for improving Striga resistance in two sorghum recombinant inbred populations. Field Crops Research, 89: 237-252.

Polhill R, Wiens DW. 1998. Mistletoes of Africa. R. Bot. Gard.: Kew, UK; 370.

Radi A. 2007. Conventional and biotechnological approaches for control of parasitic weeds. In Vitro Cell. Dev. Biol. - Plant, 43:304-317.

Rodenburg J, Bastiaans L, Kropff MJ, Van Ast A. 2006. Effects of host plant genotype and seedbank density on Striga reproduction. Weed Research, 46: 251263.

Sallé G, Boussim IJ, Raynal-Roques A, Brunck F. 1991. Le karité une richesse potentielle, perspectives de recherche pour améliorer sa production. Bois For. Trop., 228: 11-23.

Sallé G, Frochot H, Andary C. 1993. Le gui. La Recherche, 24: 1334-1342.
Sanou H, Kambou S, Teklehaimanot Z, Dembélé M, Yossi H, Sina S, Lompo D, Bouvet JM. 2004. Vegetative propagation of Vitellaria paradoxa by grafting. Agroforestry Systems, 60(1): 93-99.

Sonké B, Kenfack D, Tinto M. 2000. Parasitisme de l'avocatier (Persea americana, Lauraceae) par les Loranthacées dans la région de Yaoundé (Cameroun), Fruits, 55: 325-331.

Soro K, Soro D, N'Guessan K, Gnahoua GM, Traoré D. 2010. Parasitisme des Loranthaceae sur les hévéas en zone forestière des sous-préfectures de Gagnoa et d'Ouragahio, en Côte d'Ivoire. Journal of Animal \& Plant Sciences, 6(1): 597- 604.

Traoré D, Vincent C, Stewart RK. 1996. Association and synchrony of Smicronys guineanus and Smicronys umbrinus (Coleoptera: Curculionidea) and the parasitic weed Striga hermonthica (Del.) Benth. (Scrophulariaceae). Biological Control, 3: 307-315.

Traoré H, Ouédraogo O, Sallé G. 2000. Contrôle du Striga hermonthica (Del.) Benth. par la combinaison de la variété, du 2,4-D ou de l'arrachage au Burkina Faso. Etudes et Recherches Sahéliennes, (4-5): 86-93.

Traoré H, Hess DE, Hoffmann G, Son A, Sallé G. 2001. Use of hand-weeding and herbicides to control Striga hermonthica in Burkina Faso. African Crop Science Journal, 9: 645-653.

Wara AA. 2011. Cosmetic potentials of African shea nut (Vitellaria paradoxa) butter. Current Research in Chemistry, 3(2): 80-86. 